\title{
Dampak Film Para Pencari Tuhan Jilid X Terhadap Religiusitas Remaja
}

\author{
Robby Aditya Putra \\ UIN Syarif Hidayatullah Jakarta \\ robbyadityaputra@gmail.com
}

\begin{abstract}
This research proved that da'wa materials presented through serial religious soap opera, with good composition, can form da'wa materials which affected teenage religiosity. This research was in line with John C. Lyden in Film as Religion (2003), and Rachel Dwyer in Filming the Gods, Religion and India Cinema (2006), they contended that proselytizing activities with the media, especially film, had stronger effect to audiences, and became easier to understand than that of spoken orally. But it is present as the antithetical research of L. Rowell Huesmann in The Impact of Electronic Media Violence: The Scientific Theory and Research (2007). This research employed qualitative method by using impact analysis technique. The data gained from library study, observation, interviews, objectivity, and documentations.
\end{abstract}

Keywords: Dakwah, Communication, Film, Religion, Religiosity, Teenagers, The Seekers Of God

\begin{abstract}
Abstrak
Penelitian ini membuktikan bahwa materi dakwah yang disajikan melalui sinetron religi berseries, dengan komposisi yang tepat, dapat membuat materi dakwah lebih berpengaruh teradap religiusitas remaja.Penelitian ini senada dengan apa yang dikatakan oleh John C. Lyden dalam Film as Religion (2003) dan Rachel Dwyer in Filming the Gods, Religion and India Cinema (2006).Mereka mengatakan, bahwa kegiatan penyebaran agama dengan media, khususnya film, mampu memengaruhi audiens lebih kuat dan lebih mudah dipahami daripada hanya oral saja.Namun hadir sebagai antitesis penelitian L. Rowell Huesmann dalam The Impact of Electronic Media Violence: Scientific Theory and Research (2007), Penelitian ini menggunakan metode kualitatif, dengan teknik analisis dampak. Data-data terkait diperoleh melalui teknik studi literatur, pengamatan, pertanyaan, objetivitas, serta studi dokumentasi.
\end{abstract}

Kata Kunci: Dakwah, Komunikasi, Film Religi, Religiusitas, Remaja, Para Pencari Tuhan

\section{Pendahuluan}

Sejak dahulu, film sebagai salah satu bentuk media massa telah dijadikan alat untuk mengubah persepsi penonton. Selama perang dunia ke-2, misalnya, militer Amerika Serikat sudah memanfaatkan film sebagai bahan materi dalam pelatihan dan 
motivasi para tentara AS. Film berjudul The Battle of Britian dan Why We Fight, produksi Frank Capra, adalah dua film yang dijadikan bahan riset oleh Hovland, Lumsdaine, dan Sheffield. ${ }^{1}$ Film tersebut ditujukan untuk memengaruhi prajurit dalam tiga bidang utama. Pertama, ditujukan untuk meningkatkan pengetahuan faktual khusus para tentara. Kedua, membentuk opini-opini khusus. Ketiga, meningkatkan kesedian militer untuk mengabdi dan lebih termotivasi untuk bertempur. Kesimpulan dalam riset tersebut menyatakan bahwa dua film tersebut, cukup efektif untuk dua bidang saja, tapi sama sekali tidak berdampak pada tujuan ketiga, yaitu motivasi untuk mengabdi dan pada meningkatkan kebencian terhadap musuh.

Berbicara mengenai film dan dampaknya, ada berbagai permasalahan yang muncul dipermukaan. Tercatat sudah tujuh kali Majlis Ulama Indonesia (MUI) menyoroti film-film hasil produksi dalam negeri maupun luar negeri untuk bisa tayang di Indonesia. Sorotan ini menandakan kesadaran MUI, bahwa jika materi film menyimpang, akan dapat berdampak besar pada pemahaman dan perkembangan religiusitas masyarakat, khususnya remaja. Sampai-sampai MUI membentuk lembaga khusus untuk mengawasi konten dari media dan penyiaran yang diberi nama "Lajnah Tashih li at Ta'lif wa An-Nasyriyat Al-Islamiyah." Oleh karena itu, penayangan film di Indonesia penting dan patut diawasi secara serius.

Pada tahun 2011, MUI menyoroti film religius berjudul Tanda Tanya (?) karya Hanung Bramantiyo. Film ini dianggap sebagai materi penyebar paham sekularisme, liberalisme, dan pluralisme, sehingga MUI membentuk tim khusus untuk menyidak film tersebut. ${ }^{2}$ Padahal, seharusnya tujuan diproduksi dan ditayangkannya sebuah film adalah agar manusia mempunyai akhlak mulia, ${ }^{3}$ bukan sebaliknya. Diketahui, lewat pesona film ? (Tanda Tanya), Hanung Bramantiyo berusaha mengkritisi paham yang menganggap bahwa Islam sebagai agama radikal. Tapi nyatanya, usaha itu ditolak beberapa pihak. Mereka yang menolak beranggapan fiim ini mengandung pesan pluralisme yang kebablasan. Film tersebut menyeritakan tentang tiga keluarga beda agama tapi mampu untuk hidup dengan damai.

Selain MUI, Lembaga Sensor Film (LSF) juga turut angkat bicara. LSF merupakan lembaga yang menilai suatu film layak atau tidak layak untuk dipertontonkan kepada masyarakat. Penilaian ini berdasarkan dari segi agama, pornografi, kekerasan, suku, ras, kelompok, hukum, harkat martabat manusia dan usia penonton. Hal ini betujuan agar tidak berdampak negatif pada masyarakat. ${ }^{4}$ Diungkapkan oleh Zaitunah

${ }^{1}$ Hovland, C.I., A.A Lumsdaine, and F.D. Sheffield, Experiments on Mass Communications (Newyork: Wiley, 1949), 167-190.

${ }^{2}$ Albar, MUI Soroti Film '?'Sikap MUI terbadap film '?' karya Hanung Bramantiyo, dalam http://mui.or.id/mui/homepage/berita/berita-singkat/mui-soroti-film-karya-hanung,__diakses pada 7 April 2015, 15.25 WIB.

${ }^{3}$ Beberapa tujuan film menurut UUD diantaranya: terbinanya akhlak mulia, terciptanya kecerdasaan dan kehidupan bangsa, dikenalnya budaya bangsa oleh dunia Internasional. Lihat pasal 3 Undang Undang Dasar (UUD) Nomor 33 Tahun 2009 tentang Perfilman.

4Peraturan Pemerintah Republik Indonesia Nomor 18 Tahun 2014 tentang Lembaga Sensor Film, 1-36. 
Subhan ${ }^{5}$, semua film yang akan tayang di media/bioskop diharuskan mengantongi restu lembaga sensor film. Tanpa restu itu, rumah produksi tidak dapat tayang di layar kaca. LSF tercatat sudah berkali-kali melarang penyangan film. Tahun 2014 misalnya, Mukhlis Paeni, ketua LSF melarang penayangan film Noab, karena materi film tersebut tidak sejalan-seirama dengan kisah yang ada di Al-Qur'an. ${ }^{6}$ Nyatanya, film Noah juga dilarang tayang oleh lembaga sensor dari Qatar, Cina, Malaysia, Bahrain dan Uni Emirat Arab. Film yang menghabiskan lebih dari $\$ 125$ juta dollar itu, diambil dari kisah Bible yang inti pesannya adalah agar penonton lebih dapat menjaga Bumi. ${ }^{7}$

Upaya integrasi materi dakwah Islam dalam film diperlukan rumusan secara benar, ${ }^{8}$ sesuai dengan ajaran dan norma-norma agama Islam. Karena jika tidak, maka film dapat berdampak negatif dalam menggerakkan masyarakat pada opini yang salah, lalu akan berakibat pada peyimpangan-penyimpangan massal di masyarakat. Film berjudul ? (Tanda Tanya) dan Noah merupakan dua contoh film religious yang kontroversial. Pesan inti dari materi kedua film tersebut mengandung pesan dakwah, tapi ditolak penayangannya oleh MUI dan LSF, dikarenakan memuat unsur-unsur yang tidak sesuai dengan karakteristik pesan dakwah, yaitu al-Qur'an dan al-Hadits.

Bryan S. Turner dalam New Spiritualities, the Media and Global Religion: Da Vinci Code and The Passion of Crist meneliti dua film, yaitu Da vinci dan The Passion of Crist. Dalam temuannya, mengatakan bahwa film akan berpengaruh positif bila disesuaikan dengan kondisi keadaan agama masayarakatnya, ${ }^{9}$ Bryan mengatakan bahwa film dapat berpengaruh kepada masyarakat dengan disesuaikan dengan budaya kepercayaan suatu masyarakat, tidak berisi pelecahan, tidak menyelewengkan suatu ajaran agama bahkan mengejek kepercayaan lain secara eksplisit maupun implisit.

Film adalah salah satu bentuk media. Film sebagai mesin mimpi (dream machine), ${ }^{10}$ berupa gambar bergerak, yang di dalamnya termuat sebuah cerita yang mempunyai tujuan tertentu, berfungsi sebagai media pendidikan, hiburan, komedi, serta upaya penyebaran agama. Film terdiri atas audio dan visual, tayangan yang bersuara, bergerak dan tidak bergerak. Menurut Yudhi Munadi, media audio-visual dapat dibedakan

\footnotetext{
${ }^{5}$ Zaitunah Subhan adalah salah satu anggota lembaga sensor film (LSF) bidang advokasi dan hukum periode 2015-2019. Diambil dari presentasi Zaitunah Subhan saat mata kuliah gender, ethnicity, mayority and minority, conflict and peace. Rabu, 8 Juni 2016. Pukul 10.23.

${ }^{6}$ Ichan Suhendra, Film Noab Tidak Lolos Sensor di Indonesia. Dalam Harian Kompas, http://entertainment.kompas.com/read/2014/03/24/2311324, diakses pada 9 April 2015, pukul 17.21 WIB.

${ }^{7}$ David Manier, "What is Left Creation." Journal Psycritiques American Psychological Association, Vol. 59, No. 43, Article 8 (2014). 1-4.

8 Ropingi Ishaq, "Dakwah di Tengah Industrialisasi Media," Jurnal Komunikasi Islam. Volume 03, Nomor 01, (2013), 150.

${ }^{9}$ Bryan S. Tuner, New Spiritualities, The Media and Global Religion, dalam Pattaa Kittiarsa, Religion Commodification in Asia (London and New york: routledge Taylor and Fanncis Group, 2008), 39-44.

${ }^{10}$ Hilde D'haeyere, "Slapstick On Slapstick: Mack Sennett's Metamovies Revisit the Keystone Film Company,"Indiana University Press, Journal Film HistoryVol. 26, No. 2, (2014): 82-11.
} 
menjadi dua jenis, Pertama, audio-visual yang bergerak dan bersuara, seperti film dan video. Kedua, yang tidak bergerak tapi bersuara, seperti slide yang dimanfaatkan bersamaan dengan pemutaran musik. ${ }^{11}$ Audio-visual bergerak mempunyai kelebihan tersendiri dari tidak bergerak, yang mampu menunjukkan inti materinya dengan lebih jelas dan dalam jika dibandingkan dengan yang tidak bergerak.

Paul Wolfram mengatakan, film yang bisa disebut sebagai seni bercerita dengan audio-visual, sangat berpengaruh pada sejarah sosial-budaya dan juga sikap masyarakat. ${ }^{12}$

John C. Lyden mengatakan metode pengembangan film yang diinformasikan oleh wawasan pendidikan agama, dapat berbicara sangat kuat di dalam suatu budaya. ${ }^{13}$ Film sebagai audio-visual mempunyai banyak kelebihan dalam upaya membantu dakwah dalam menyebarkan kebaikan dan mencegah kemungkaran. Audio-visual berupa gambar yang bergerak, membentuk sebuah cerita dan pesan. Oleh karena itu, dakwah akan lebih berdampak bila dilakukan dengan berbagai cara, salah satunya melalui audio-visual.

Eksistensi Para Pencari Tuhan selama sepuluh tahun dengan karakteristiknya yang religious-humoris, menimbulkan sebuah pertanyaan mayor dalam benak penulis. Apakah film yang sudah tayang sepuluh tahun ini mempunyai dampak signifikan terhadap perkembangan religiusitas penontonnya, dalam hal ini remaja? Mengingat film tersebut tergolong pada film religi khas Ramadhan laris Indonesia yang mempumyai rating-share tinggi dan telah menyabet berbagai penghargaan.

\section{Bingkai Teoritis dan Metode Penelitian}

\section{Bingkai Teoritis}

Bagan di bawah ini menjelaskan bingkai teori yang dapat membantu menguraikan skema dan alur dalam proses penelitian ini. Film religiusus Para Pencari Tuhan jilid $\mathrm{x}$ akan diteliti dan dianalisis dampaknya terhadap perkembangan religiusitas remaja. Adapun konsep yang dipakai untuk mengukur tingkat religiusitas remaja pra dan pasca menonton film tersebut adalah menggunakan teori CMIR (Comprehensive Measure of Islamic Religiousity). ${ }^{14}$ Sedangkan, untuk mengukur seberapa jauh dan dalam dampak yang timbul dari kedua fim tersebut, akan dibedah menggunakan dua teori dampak, yaitu teori jarum suntik dan Uses and Gratifications yang disajikan melalui kuesioner, wawancara mendalam, pengamatan kepada remaja yang dijadikan sampel dalam ruang lingkup sekolah,

11Yudhi munadi, Media Pembelajaran Referensi (Jakarta: GP Press Groupmaret, 2013), 113.

${ }^{12}$ Paul Wolfram, "Career View, What is film?"Career Development and Employment, University Of wellington, Issue No 59. (2011) 2-4.

${ }^{13}$ John C. Lyden, Film as Religion; Myth, Moral and Ritual, (USA, Network University Press, 2003). 246-248.

${ }^{14}$ Habib Tiliouine dan Abbes Belgoumidi, "An Exploratory Study of Religiousity, Meaning in Life and Subjective Wekkbeing in Muslim Students From Algeria," The Internasional Society for Quality of Life Studies (SQOLS) 4 Springer (2009), 119. 
dalam hal ini remaja Lampung. Setelah itu, peneliti akan menemukan hasil data lapangan, kemudian dari hasil tersebut akan dikontruksikan sebagai kesimpulan dengan analisis menggunakan teori-teori tersebut di atas terkait dampak film dan tingkat religiusitas responden. Akhirnya, hasil analisis akan ditemukan dari perbedaan dan persamaan sebelum dan sesudah menonton.

\section{Bagan Bingkai Teori}

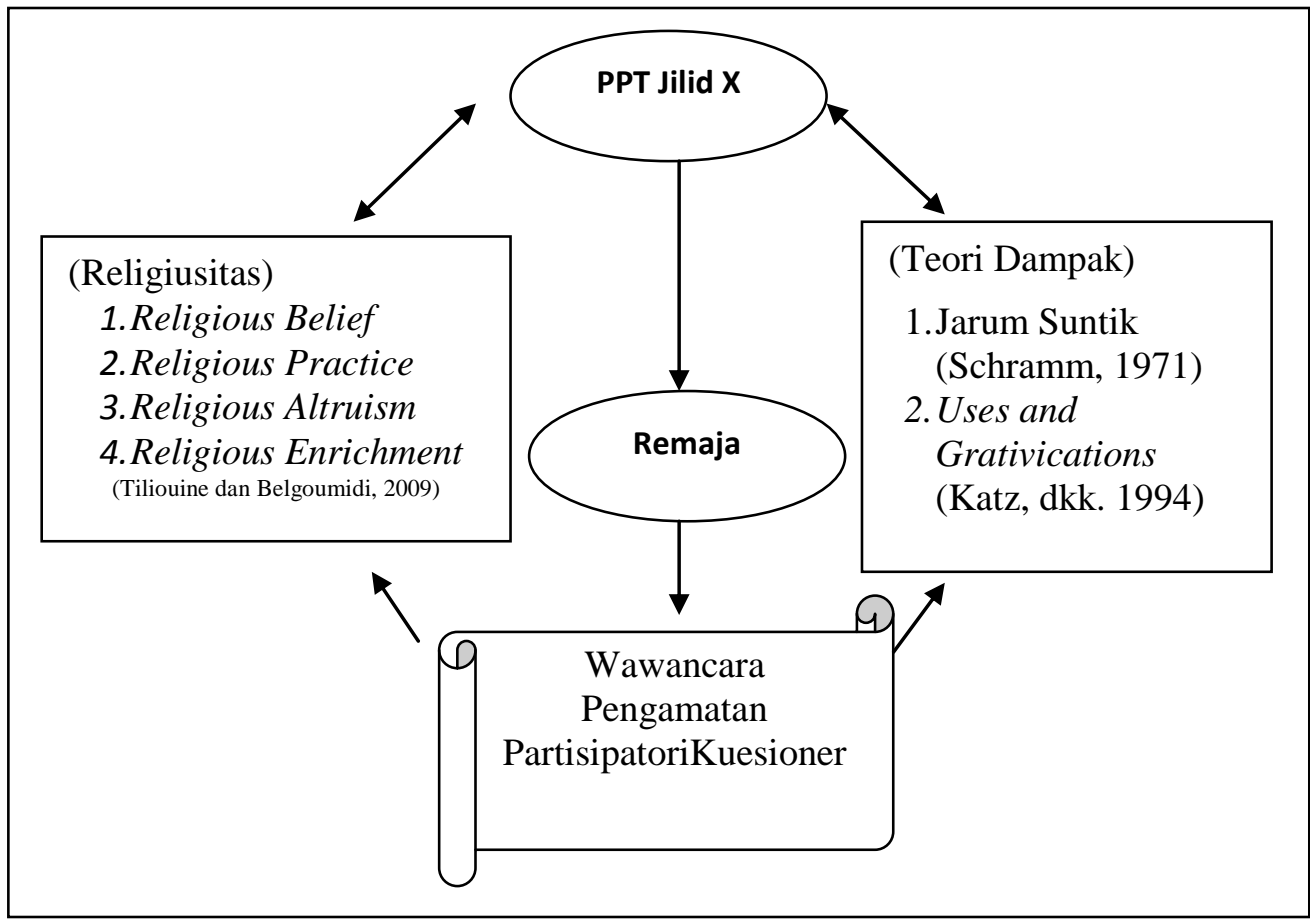

2. Metode Penelitian

Tingkat pengaruh film Para Pencari Tuhan jilid $\mathrm{x}$ dengan pembentukan religiusitas remaja ditentukan oleh beberapa konsep/kata kunci, yaitu religious belief, religious practice, religious altruism, religious enrichment yang dipadukan dengan teori dampak Uses and Gratifications dan jarum suntik. Setalah didapat kerangka penelitiannya, kemudian menggambarkan konsep dan variabel yang akan diteliti. Adapaun bingkai alur penelitian dapat dilihat pada bagan 4 pada halaman 27. Penelitian dalam rangka penulisan tesis ini jika dilihat dari lokasi dan sumber data termasuk kategori penelitian lapangan (field research). ${ }^{15}$ Dan ditinjau dari sifat-sifat

${ }^{15}$ Penelitian lapangan adalah penelitian untuk mencari peristiwa dalam objek penelitian belangsung sehingga mendapatkan informasi langsung dan terbaru tentang masalah yang berkenaan, sealigus sebagai cross checking terhadap bahan-bahan yang telah ada. Talizusuhu Ndraha, Research, Teori, Metodologi, Administrasi (Jakarta: Bina Askara, 1981), 116. 
data maka termasuk dalam kategori penelitian kualitatif. ${ }^{16}$ Meskipun menurut Wardi Bactiar dalam dunia riset, tidak dikenal metode kualitatif maupun kuantitatif, yang ada adalah data kualitatif dan data kuantitatif. ${ }^{17}$ Metode yang penulis gunakan dalam penelitian ini adalah metode kualitatif dan kuantitatif, sehingga untuk membedakannya dengan kuantitatif murni, seperti yang dikatakan Deddy Mulyana bahwa metode penelitian kualitatif tidak mengandalkan bukti berdasarkan logika matematis, prinsip angka ataupun statistik. Pembicaraan yang sebenarnya, isyarat dan tindakan sosial lainnya adalah bahan mentah untuk analisis kualitatif.

Alasan dipilihnya metode ini adalah didasarkan kepada pertimbagan bahwa masalah film religius dan religiusitas ini berada dalam wilayah kajian budaya, mengungkapkan religiusitas merupakan suatu metode yang bersumber dari hal yang dikatakan seseorang, prilaku seseorang dan berbagai instrument/benda yang digunakannya, sehingga ketika mengambil suatu kesimpulan religiusitas harus berdasarkan prinsip empiris dan tidak bisa dicampur dengan prinsip-prinsip logika semata.

Fokus peneletian ini tentang permasalahan dampak film religius Para Pencari Tuhan terhadap pembentukan religiusitas remaja, dan akan dikomparasikan tingkat kedampakannya sebelum dan sesudah menggunakananalisis dampak, sehingga diperlukan penelitian lapangan, di mana membutuhkan lokasi, manusia sebagai pengumpul data dan koresponden sebagai salah satu ciri dari pendekatan kualitatif.

Penelitian ini mengunakan alat ukur (skala) religiusitas CMIR (Comprehensive Measur of Islamic Religiousity) yang diadaptasi dari Habib Tillioune dan Abbes Belgoumidi. Alat ukur ini terdiri dari 4 indikator, yaitu: Religious Belief, Religious Practice, Religious Altruism, dan Religious Enrichment. ${ }^{18}$ Alat ukur ini dianggap cocok untuk digunakan dalam penelitian ini, karena sesuai dengan sosologi-psikologi remaja yang menjadi sampel dalam penelitian ini, tidak terlalu banyak dan juga tidak terlalu sedikit.

Religious Belief terdiri dari sembilan item yang berhubungan erat dengan keyakinan dan keimanan, seperti percaya kepada Allah, Rasul Allah, hari pembalasan, neraka, surga, mukjizat Al-Quran, dan kada dan kadar Allah. Religious Practice terdiri dari lima item yang berhubungan dengan praktik ibadah, yaitu shalat, puasa, menutup aurat, menghindari judi, dan minuman beralkohol. Religious

16 Penelitian kualitatif adalah penelitian yang mengandalkan manusia sebagai alat penelitian, memanfaatkan metode kualitatif, mengadakan analisis data secara induktif, bersifat deskriptif, lebih mementingkan proses daripada hasil, membatasi studi pada fokus, dari hasil penelitiannya disepakati oleh kedua belah pihak. Lexy J Moleong, Metodelogi Penelitian Kualitatif (Bandung: Remaja Rosdakarya, 2006), 150-152.

17 Wardi Bactiar, Metodologi Penelitian Dakwah (Jakarta: Logos, 1997), 21-23.

18 Habib Tiliouine dan Abbes Belgoumidi, "An Exploratory Study of Religiousity, Meaning in Life and SubjectiFe Wekkbeing in Muslim Students From Algeria," The Internasional Society for Quality of Life Studies (SQOLS) 4 Springer (2009), 119. 
Altruism terdiri dari delapan item yang berhubungan kepedulian dan kasih sayang sesama manusia yaitu bersedekah, tolong menolong, dan peduli terhadap kesejahteraan orang lain. Religious Enrichment terdiri dari dua item yang berhubungan meningkatkan pengetahuan keagamaan, yaitu membaca buku keagamaan dan menghadiri pengajian.

Tabel 1. Aspek-Aspek Pengukuran Religiusitas

\begin{tabular}{ll}
\hline Religiusitas & Aspek-aspek pengukuran \\
Religious Belief & Keimanan Remaja \\
Religious Practice & Praktik Peribadatan Remaja \\
Religious Altruism & $\begin{array}{l}\text { Kepedulian dan Kasing Sayang } \\
\text { terhadap Sesama }\end{array}$ \\
Religious Enrichment & Kesadaran untuk Menambah \\
& Ilmu \\
\hline
\end{tabular}

\section{Hasil Dan Pembahasan}

Dalam kehidupan sehari-hari, masyarakat lebih memperhatikan tata cara pelayanan memberikan sesuatu, dari pada inti sajian itu sendiri. Segelas air putih yang disajikan dengan sopan, ramah, beretika, dan berbasis teknologi, akan lebih terasa efeknya, dibandingkan segelas jus apel lezat yang disajikan dengan tidak sopan, kurang ajar, buta teknologi, bahkan menyakiti hati orang yang menerimanya. Hal ini paralel dengan dakwah. Sesempurnanya materi dakwah, jika disampaikan dengan cara yang jauh dari etika, tidak berbasis teknologi, maka akan menimbulkan sikap tidak menggembirakan, memilukan, tidak berdampak baik untuk klasifikasi masyarakat tertentu. Bahkan akan terjadi penolakan. Jangan sampai ini terjadi.

Moh Ali Aziz dalam bukunya Ilmu Dakwah berusaha memetakan perkembangan pendefinisian dakwah. Dia menggolongkan tiga kecondongan para ahli dalam memaknai dakwah. Pertama, para akademisi Indonesia yang menitikberatkan aspek metode dakwah dalam usaha mendefinisikan dakwah. Kedua, penulis Timur-Tengah yang lebih menekankan aspek pesan dakwah. Ketiga, para peneliti barat yang melihat makna dakwah dari aspek sosiologis. ${ }^{19}$ Dari segi etimologis, ungkapan kata dakwah berasal dari bahasa Arab, yaitu da'a, yad'u, da'wan, du'a, ${ }^{20}$ yang diartikan sebagai

${ }^{19}$ Setidaknya terdapat empat puluh delapan definisi dakwah berasal dari abstraksi pemikiran para ahli di Indonesia, Timur Tengah dan Barat yang berusaha dipetakan oleh Moh.Ali Aziz. Lihat Moh. Ali Aziz, Ilmu Dakwah (ed) Jakarta: Kencana, 2011), 34-40. Sama hal nya seperti yang dikatakan oleh Bakhial Khauli dalam Ghazali Darussalam, Dinamika Imu Dakwah (Malaysia: Mur Siagag SDN, 1996), 5 dan Al-Ghazali dalam Munzier Suparta, Metode Dakwah (Jakarta: Kencana, 2003), 1-7. Mereka mengatakan bahwa dakwah adalah kegiatan menghidupkan amar ma'ruf nabi munkar dalam kehidupan bermasyarakat.

${ }^{20}$ Majma, al-Lughah al-Arabiyah, 1972:286. 
mengajak, memanggil, seruan, permohonan dan permintaan. Sedangkan, berdasarkan Al-Qur'an, dakwah diartikan sebagai perintah menyerukan manusia pada ajaran Tuhan dengan hikmah, pengajaran yang baik dan mujadalah. ${ }^{21}$ Dakwah juga dikatakan sebagai kegiatan yang menyerukan kebajikan, amar ma'ruf nabi munkar, dan mencegah kemungkaran ${ }^{22}$

Perlu diakui, definisi dakwah itu sangat beragam. Quraish Shihab, mengartikan dakwah sebagai seruan atau ajakan kepada keinsyafan, atau usaha mengubah sesuatu yang belum baik menjadi baik dan menuju tingkat sempurna. ${ }^{23}$ Menurut Ahmad Syafi'i Ma'arif, dakwah adalah kegiatan yang bertujuan untuk memancing dan mengharapkan potensi fitri manusia agar eksistensi mereka mempunyai makna di hadapan Tuhan dan sejarah. Dia juga menegaskan tugas dakwah adalah tugas seluruh umat manusia, bukan sebagian saja. ${ }^{24}$ Kemudian Toto Asmara menyebutkan istilah dakwah sama dengan tabligh, yaitu sebagai proses penyampaian atas pesan-pesan tertentu yang berbentuk ajakan dan seruan dengan tujuan agar orang lain memenuhi ajakan tersebut. ${ }^{25}$ Tetapi, jika diperhatikan keberagaman makna dakwah ini mengerucut menjadi satu seragam, yaitu proses menyebarkan pesan kebaikan agar komunikan berubah menjadi lebih baik.

Kemudian, kata "komunikasi," 26 mempunyai arti sebagai suatu proses pertukaran (baik fikiran, perasaan atau informasi) oleh sesorang kepada orang lain yang memiliki kesamaan makna dan tujuan tertentu. ${ }^{27}$ Frank E. X Dance menginventarisasi 126 definisi komunikasi berbeda. Dari 126 definisi tersebut Dance menyimpulkan ada 15 komponen konseptual pokok dari komunikasi, yaitu 1) simbol-simbol, verbal dan anjuran, 2) Pengertian 3) Adanya interaksi 4) Pengurangan rasa ketidakpastian, 5) proses sosial 6) Pertukaran, 7) Menghubungkan, 8) Kebersamaan, 9) Saluran atau alat, 10) Memori, 11) Tanggapan diskriminatif, 12) Stimulan, 13) Tujuan dan dampak, 14) Waktu dan situasi, dan 15) Kekuasaan. ${ }^{28}$ Bakti mengatakan bahwa sebenarnya komunikasi adalah proses negoisasi, karena pesan yang disampaikan komunikator harus bernegoisasi dengan kultur, latar belakang komunikan, yaitu, cara pandang dunia, kebiasaan sehari-hari, nilai-nilai, keyakinan, orientasi, serta apapun yang mereka miliki

21 Al-Qur'an surat An-Nahl, ayat 125.

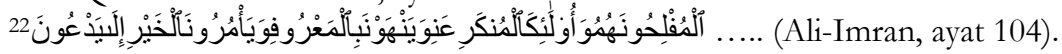

${ }^{23}$ M. Quraish Shihab, Membumikan Al-qur'an (Bandung: Mizan, 1994), 194-196.

24 Siti Uswatun Hasanah, Berdakwah dengan Jalan Debat antara Muslim dan Non-Muslim (Yogyakarta: Pustala Pelajar dan STAIN Press, 2007), 26.

25 Toto Asmara, Komunikasi Dakwah (Jakarta: Gaya Media Pratama, 1998), 31-32.

${ }^{26}$ Komunikasi mempunyai makna yang beragam tergantung siapa dan dari angel mana ia memotret komunikasi. Lihat misalnya dalam Andi Bulaeng, Metode Penelitian Komunikasi Kontemporer (Jogjakarta: Andi, 2004), 24. Alwi Dahlan, “Teknologi Informasi dan Demokrasi," Jurnal Ikatan Sarjana Ilmu Komunikasi Indonesia, Vol. IV/Oktober 1999, Bandung: Remaja Rosdakarya, 4-7. Bandingkan Dengan Andi Faisal Bakti, Communication and Family Palnning in Islam in Indonesia: South Sulawesi Muslim Perception of A Global Development Program (Leiden: INIS, 20014), 13.

${ }^{27}$ Dani Vardiansyah, Pengantar Imu Komunikasi (Bogor, Ghalia Indonesia, 2004), 4-7.

28 Stephen W. Littlejohn, Theories of Human Communication (California: Wadworth Publishing Company, 2005), 6-8. 
sebelumnya. Tanpa hal itu, sukar bagi sebuah pesan untuk mengubah suatu masyarakat.Apalagi jika pesan tersebut bertujuan untuk melahirkan budaya yang baru. ${ }^{29}$

Oleh karena dakwah dan komunikasi memiliki kesamaan secara fundamental, maka untuk mengetahui makna dakwah secara utuh, kita dapat meminjam teori Laswell yang mengatakan bahwa untuk mengetahui proses komunikasi secara komprehensif, perlu menjawab pertanyaan (Who) siapa yang mengatakan? (Says What) mengatakan tentang apa? (Which Channel) menggunakan media apa? (To Whom) kepada siapa? dan (With What Effect) menghasilkan efek apa?30 Siapa da'i yang menyampaikan pesan dakwah? Sesuaikah pesan yang disampaikan dengan karakteristik pesan dakwah? Melalui media modern atau konvensional? Klasifikasi masyarakat dakwah nya bagaimana? Kemudian dari proses tersebut, komunikator mengharapkan dan menghasilkan dampak apa?

Andi Faisal Bakti menyatakan bahwa kemandirian ilmu dakwah sulit dicapai jika tidak diintegrasikan dengan ilmu komunikasi. Menurutnya, agar dakwah menjadi ilmu yang mandiri dan memiliki epistimologi yang jelas perlu mengadopsi teori-teori yang berasal dari ilmu komunikasi yang sudah kokoh keberadaannya. Sehingga penafsiran modern dari nilai-nilai Islam harus dibawa ke dalam komunitas yang lebih luas agar Islam dapat dan mudah dipahami. Dengan demikian, perkembangan ilmu dakwah tidak hanya berkutat pada wacana apakah dakwah itu ilmu atau hanya pengetahuan saja. ${ }^{31}$

Tabel Perbandingan Unsur-Unsur Dakwah dan Komunikasi.

\begin{tabular}{clll}
\hline No & Dakwah & Komunikasi & \multicolumn{1}{c}{ Lasswel } \\
\hline $\mathbf{1}$ & Da'i & Komunikator & Who? \\
$\mathbf{2}$ & Mad'u & Audiens & To Whom? \\
$\mathbf{3}$ & Wasilah & Media & Which Channel? \\
$\mathbf{4}$ & Maddah & Materi & Says What? \\
$\mathbf{5}$ & Umpan Balik & Feed Back & With What Effect? \\
\hline
\end{tabular}

Unsur pertama dakwah dan komunikasi adalah sama-sama komunikator. Komunikator dalam komunikasi dan dakwah adalah pihak yang memprakarsai dan mengarahkan tindakan komunikasi. Komunikator/da’i dapat dibedakan dalam wujud individu, lembaga ataupun berupa sekumpulan beberapa orang. Jika seorang tokoh bertindak sebagai sumber komunikasi, maka ia dapat dilihat sebagai sumber individual (individual source). Sedang dalam momentum lain, meskipun yang berbicara adalah

29 Andi Faisal Bakti, Communication and Family Planning in Islam in Indonesia: South Sulawesi Muslim Perception of a Global Development Program (Leiden: INIS, 20014), 13.

30 Denis McQuail and Seven Windahl, Communication Models for Study of Mass Communications (New York: Longman, 1993), 14-16.

${ }^{31}$ Andi Faisal Bakti, Applied Communication to Dakwah for Peace, makalah dipresentasikan pada kuliah umum di Pascasarjana UIN Alauddin Makassar, 1 September 2009. 
individu namun dia mewakili sebuah lembaga/organisasi maka dia dipandang bukan sebagai individu lagi, melainkan sebagai sumber kolektif (collective source). ${ }^{32} \mathrm{Hal}$ ini juga berlaku untuk proses dakwah. Tentunya dengan kualifikasi tertentu.

Dari kelima unsur tersebut, dampak adalah yang paling penting dari proses komunikasi ataupun dakwah. Bagaimana tidak, dampak adalah destinasi akhir dari proses komunikasi maupun dakwah. Contoh kecilnya begini, akitivitas seperti seorang ayah menasehati anaknya, sebuah iklan membujuk calon konsumennya, para artis menghibur penontonnya di televisi, kakak menertawakan adiknya, psikolog membangkitkan semangat kliennya, merupakan sebuah proses komunikasi yang mengharapkan dampak dari perubahan pemahaman, pemikiran dan tindakan. Semua aktivitas komunikasi/dakwah tersebut bisa menimbulkan, mendorong, dan memberikan pegaruh kepada komunikan. Tapi bisa juga sebalik nya, tanpa pengaruh apapun.

Berdiskusi mengenai dampak, dampak merupakan ujung tombak dan tolok ukur keberhasilan proses komunikasi dan dakwah (komunikasi Islam). ${ }^{33}$ Beragam teori dampak pun muncul. Banyak para ahli yang telah memformulasikan teori-teori dampak untuk dijadikan sebuah kajian. Secara garis besar teori dampak dapat dibagi menjadi dua rumusan. Pertama adalah rumusan 'mainstream' yang berangkat $\backslash$ dari media ke audiens. Artinya, rumusan teori pengaruh ini memusatkan bahwa medialah yang memainkan peran besar dalam memengaruhi audiens. Teori stimulus respon, jarum suntik, agenda setting, pengaruh terbatas adalah contoh teori ini. Kedua rumusan teori 'anti-mainstream' yang berangkat dari audiens ke media.Artinya, teori-teori ini memusatkan bahwa audienslah yang secara aktif memilih berpengaruh atau tidak berpengaruhnya suatu media, bukan media itu sendiri. Uses and Gratifications, resepsi akif, uses and effect dan spiral kesunyian adalah contoh dari rumusan teori 'anti-mainstream' ini.

\section{Bagan Teori Dampak}

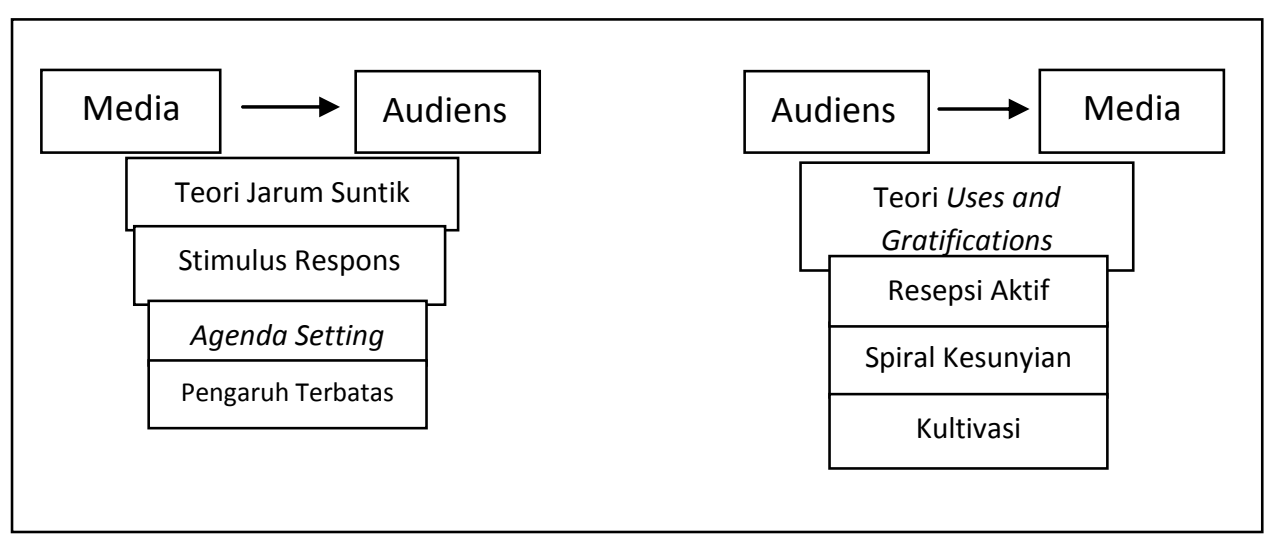

32 Deddy Mulyana, Imu Komunikasi: Suatu Pengantar (Bandung: Remadja Rosdakarya, 2000), 83-120.

${ }^{33}$ Arvind Kumar, Encyclopedi of Mass Media and Communication (New Delhi: Anmol Pulication PVT. LTD, 1998), 149-151. 
Perubahan-perubahan yang terjadi dalam diri responden dan lingkungan akan menimbulkan dampak terhadap pembentukan religiusitas remaja itu sendiri. Dalam penelitian ini, responden dalam penggalian data ditujukan untuk mengetahui hubungan para pencari tuhan terhadap religiusitas remaja. Konsep untuk mengidentifikasi sumber data dalam penelitian ini terdiri dari beberapa konsep, yakni jenis kelamin, usia, frekuensi intensitas menonton televisi, pengetahuan tentang sinetron para pencari tuban jilid $\mathrm{x}$ dan kondisi religiusitas.

\section{Diagram Distribusi Responden Berdasarkan Jenis Kelamin}

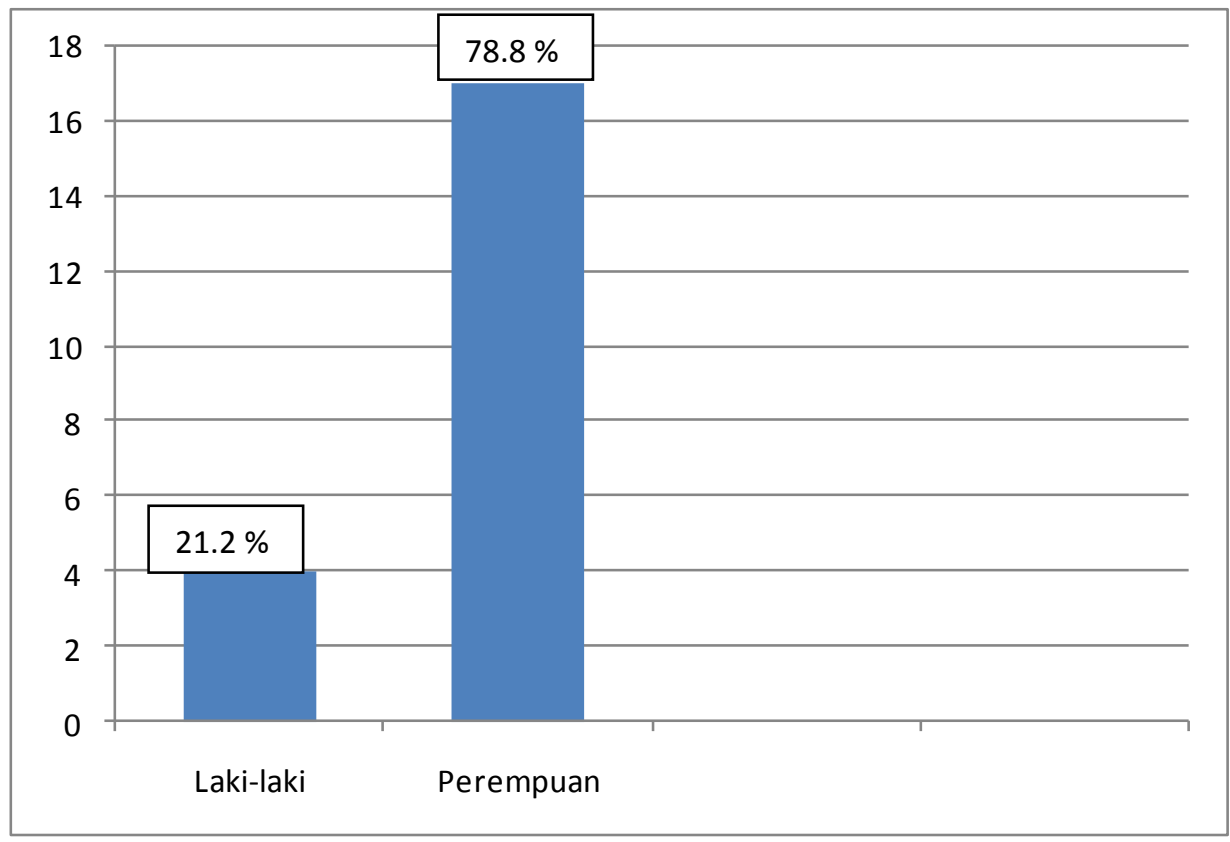

Diagram di atas menjelaskan distribusi responden dari sisi jenis kelamin. Jumlah responden dalam penelitian ini adalah 21 orang. Adapun prosentase responden adalah laki-laki sebanyak 4 orang $(21,2 \%)$ dan responden perempuan sebanyak 17 orang $(78,8$ $\%$ ). Berdasarkan data keseluruhan siswa yang penulis dapatkan dari staf tata usaha, dari kelas X, XI dan X11 memang wanita merupakan jender yang paling banyak, dibandingkan dengan jender laki-laki. Ketimpangan ini bukan berarti melegitimasi anggapan bahwa dunia sudah diambang pintu kiamat. Diungkapkan Herbos Siregar bahwa ketika tes pendaftaran masuk, terlihat didaftar absen, laki-laki lebih banyak dari perempuan. Akan tetapi, kebanyakan nilai yang tinggi yang memenuhi ekspektasi sekolah sehingga bisa masuk menjadi murid SMAN 1 Sekud adalah perempuan, 
sedangkan laki-laki dibawah standar nilai. ${ }^{34}$ Jadi sebenarmya, jumlah laki-laki dan perempuan di sekolah ini bukanlah berlandaskan pada kuantitas, tapi kualitas.

Dari segi usia, distribusi responden mempunyai empat katagori umur, yaitu umur 15, 16 , 17 dan 18 tahun. Hal ini wajar, karena mengingat responden adalah pelajar sekolah menengah atas yang rerata berusia 15-18 tahun. Prosentase nya responden yang berusia 15 Tahun adalah 4 orang $(18.1 \%)$, responden yang berusia 16 tahun adalah 15 orang $(72.2 \%)$, responden yang berusia 17 tahun adalah 2 orang $(9.1 \%)$, dan responden yang berusia 18 tahun tidak ada. Dari data tersebut diketahui bahwa bahwa usia responden terbanyak adalah 16 tahun dengan 24 (72.2\%), di mana termasuk pada remaja awal. Disusul dengan usia 15 tahun, kemudian 17 tahun.

\section{Diagram Distribusi Responden Berdasarkan Umur}

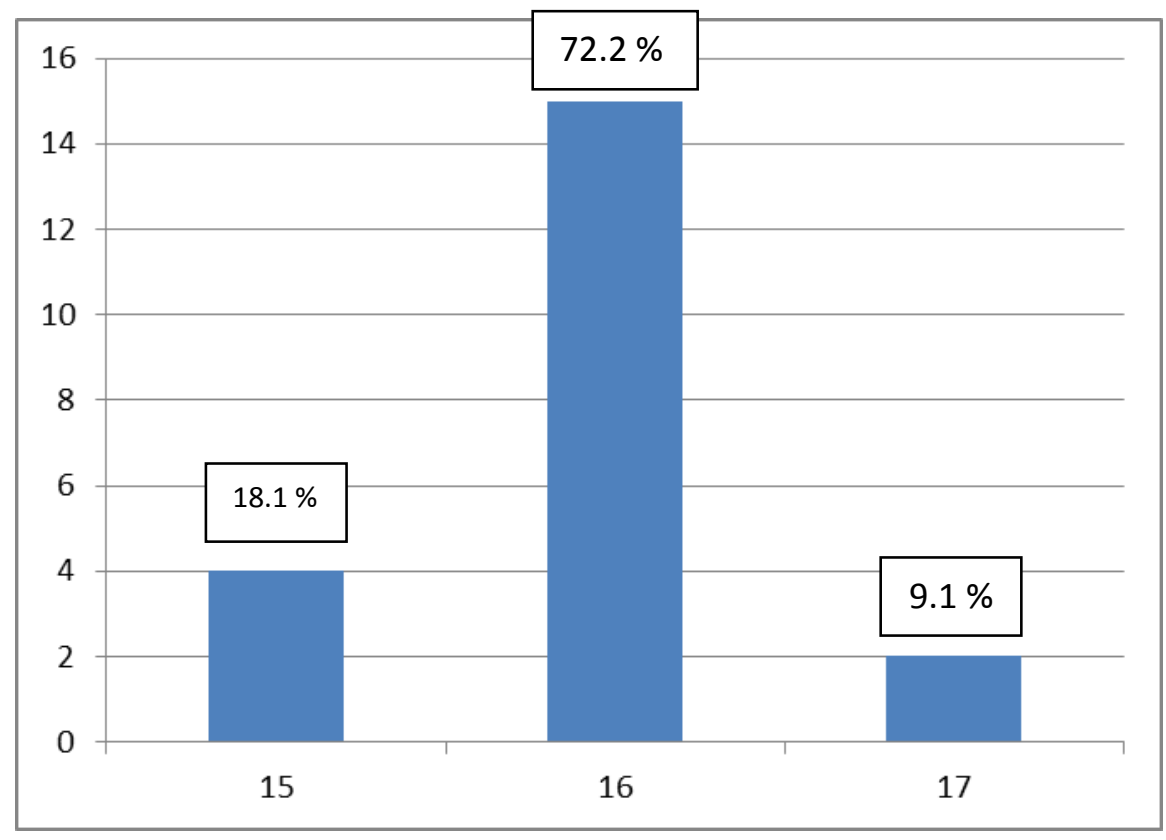

Adapaun rincian detail terkait nama, jenis kelamin dan usia respoden dapat dilihat pada tabel di bawah ini:

Tabel2. Nama, Jenis Kelamin dan Usia Respoden

34 Wawancara dengan Herbos Sidari, waka kurikulum SMAN 1 Sekampung Udik Lampung Timur, tanggal 11 Mei 2016. 


\begin{tabular}{|c|c|c|c|c|}
\hline No & Nama & Kelas & Umur & $\begin{array}{c}\text { Frekuensi Menonton } \\
\text { Dalam Seminggu }\end{array}$ \\
\hline 1. & Kurnia Mala Sari & XI R & 16 tahun & $6 \mathrm{kali}$ \\
\hline 2. & Winda Marlina & XI R & 15 tahun & 6 kali \\
\hline 3. & Siti Nur Hasanah & XI R & 16 tahun & 5 kali \\
\hline 4. & Arni Anggriani & XI R & 16 tahun & 4 kali \\
\hline 5. & Wanda Okta Viandini & XI R & 16 tahun & 7 kali \\
\hline 6. & Feby Silvia Karawati & XI R & 16 tahun & 4 kali \\
\hline 7. & Tri Anggraeni & XI R & 17 tahun & 4 kali \\
\hline 8. & Anggi Widiayu Ningsih & XI R & 16 tahun & 2 kali \\
\hline 9. & Wardah Kartika Sari & XI IPA 2 & 15 tahun & 5 kali \\
\hline 10. & Sumi Apri Yani & XI IPA 2 & 16 tahun & 7 kali \\
\hline 11. & Faridatul Mahfudhoh & XI IPA 2 & 16 tahun & 4 kali \\
\hline 12. & Eka Wahyu Safitri & XI IPA 2 & 16 tahun & $\backslash 6$ kali \\
\hline 13. & Serly Oktavia Monica & XI IPA 2 & 16 tahun & 5 kali \\
\hline 14. & Linda Ayu Astuti & XI IPA 2 & 16 tahun & 4 kali \\
\hline 15. & Salma Septiyansyah & XI IPA 2 & 15 tahun & 4 kali \\
\hline 16. & Meriyana & XI R & 17 tahun & 6 kali \\
\hline 17. & Tiara Yunita & XI IPA 2 & 15 tahun & 4 kali \\
\hline 18. & Yanwar Baskoro & XI R & 16 tahun & 3 kali \\
\hline 19. & Effendi Bustomi & XI IPA 2 & 16 tahun & 6 kali \\
\hline 20. & Nur Arif Wijayanto & XI IPA 2 & 16 tahun & 3 kali \\
\hline 21. & Argo Purwanto & XI IPA 2 & 16 tahun & 5 kali \\
\hline
\end{tabular}

\section{Aspek Praktek Shalat}

Perlu peneliti tekankan, bahwa ada dua tahap penjabaran. Hal ini penting di garis bawahi agar tidak terjadi bias penafsiran oleh pembaca. Jadi ada dua tahap.Tahap pertama adalah wawancara dan pengamatan sebelum menonton. Tahap kedua adalah wawancara dan pengamatan setelah responden menonton Para Pencari Tuhan jilid x.

Di bagian ini peneliti akan memaparkan hasil wawancara terkait aspek religious practice. Seperti yang sudah dipaparkan dalam bab sebelumnya, bahwa pada aspek religious practice peneliti hanya akan menekankan pada poin pelaksanaan "shalat" saja. 
Begitu juga dengan aspek Religious Altruism, peneliti akan fokus pada poin "Peduli sesama manusia." Religious Enrcicment akan fokus pada kesadaran responden terkait "Membaca buku-buku agama." Ini dilakukan agar penelitian tetap fokus, objektif dan terukur.

Dari obrolan yang berhasil direkap, dapat di pahami bahwa kondisi ketaatan religious practice responden dalam hal shalat masih tergolong cukup rendah.Mengingat sebagian dari mereka masih bolong-bolong melaksakan shalat.20 responden mengatakan hal demikian, khususnya shalat Dzuhur, Ashar dan Isya. Alasannya nampak seragam, yaitu kelelahan, terlalu sibuk mengerjakan tugas, keasyikan bermain, yang berujung pada kemalasan. Padahal, dalam Islam sebagai salah satu bentuk ibadah yang amat simbolik untuk kesadaran akan kehadiran Tuhan adalah dengan mendirikan shalat. Shalat adalah praktek yang membina 'kontak' dengan Tuhan. Inilah yang menjadi tujuan utama dari shalat.Dalam ritual shalat, sesungguhnya seorang hamba diharapkan menghayati sedalam-dalamnya kehadiran Tuhan dalam hidup ini, sebagaimana sabada Rasulullah yang artinya, "Beribadah kepada Allah SWT seakan-akan engkau melihat-Nya, dan seandainya engkau tidak bisa mencapai keadaan itu, engkau harus yakin babwa Dia melihatmu." (HR Bukhari). Shalat yang komprehensif adalah shalat yang dilakukan dengan keyakinan, kekhusyukan dan kehadiran hati yang disertai ketenangan (thuma'ninab) seluruh anggota badan. Shalat itu membentuk rasa keagamaan serta religiusitas yang sangat tinggi. ${ }^{35}$

Nyatanya, ada dua bentuk komunikasi antara manusia dengan Allah, pertama komunikasi yang terjadi atas kehendak Allah.Bentuk komunikasi pertama ini terjadi antara manusia dengan Allah murni karena kehendak Allah. Komunikasi bentuk pertama ini semata-mata kehendak Allah swt tanpa adanya usaha yang dilakukan manusia. Komunikasi tersebut berupa penyampaian wahyu dan kalam dibalik tabir atau hijab. Seperti wahyu yang tutun kepada nabi Muhammad SAW. Kedua adalah bentuk komunikasi yang terjadi karena adanya usaha yang dilakukan manusia. Ibadah shalat merupakan salah satu bentuk komunikasi ini. Shalat sengaja didesain oleh Allah SWT agar manusia dapat berkomunikasi dengan-Nya. Model komunikasi yang dikehendaki oleh Allah SWT terhadap manusia adalah memuji, bertasbih, bertaahmid, berdzikir, bertahlil serta memohon doa dan petunjuk jalan yang benar dan dijauhkan dari jalan yang sesat. ${ }^{6}$ Sungguh kalau manusia menyadari, perjumpaan dengan-Nya dalam shalat adalah perjumpaan yang paling indah dan menyenagkan.

Dari pernyataan di atas, nampaknya responden belum menghayati secara benar bahwa shalat adalah kewajiban peribadatan yang penting dalam sistem keagamaan Islam. Ayat-ayat Tuhan banyak memuat perintah agar umat Islam mendirikan shalat dengan penuh kesungguhan yang kemudian digambarkan bahwa kebahagiaan kaum beriman adalah karena shalatnya dilakukan dengan penuh kekhusyukan. ${ }^{37}$ Semestinya

${ }^{35}$ Nurcholis Madjid, Islam Doktrin dan Peradaban (Jakarta: Paramadina, 1992), 57-58.

36 Andang B. Malla, Merasakan Allah dalam Shalat (Jakarta: RabbaniPress, 2009), $42-47$.

${ }^{37}$ Sesunggubnya beruntunglah orang-orang yang beriman (1).(Yaitu) orang-orang yang khusyu' dalam shalatnya (2). (Q.S Al-Mu'minun, 23:1-20). 
responden sudah menyadari hal ini, mengingat usia mereka yang sudah baligh. Akan tetapi, fenomena ini juga tidak serta merta kelalaian dari responden, tetapi juga kelalaian orang tua, guru dan lingkungan sekitar.

Dengan melihat fakta demikian, satu hal yang niscaya ditegaskan adalah tradisi keislaman yang berkembangan di lingkungan SMAN 1 Sekampung Udik sangat memengaruhi praktek shalat siswa-siswanya. Artinya secara praktek, dakwah bil-hal guru dan murid miliki hubungan erat, bahkan dalam batas tertentu sulit dipisahkan. Bila gurunya mencontohkan hal baik, mecontohkan shalat secara berjamaah di masjid, maka muridnya pun akan melakukan demikian. Demikianlah kondisi religious practice (shalat) responden satu bulan sebelum sinetron Para Pencari Tuan tayang. Tapi yang perlu dipertanyakan selanjutnya adalah, apakah pilihan acara televisi responden juga ikut andil dalam memengaruhi aspek religious practice (shalat)? Dalam hal ini yang ditekankan adalah fim Para Pencari Tuban jilid x.

Apa yang tampak adalah gambaran sederhana dampak Para Pencari Tuban jilid $\mathrm{x}$ terhadap praktek shalat sesuai pengakuan responden. Merekalah orang yang merasakan secara langsung sejauh mana pengaruh sinetron ini terhadap religiusitasnya. Tidak ada paksaan dalam menjawab. Wawancara mengalir lancar, tanpa intervensi apapun. Terlihat secara verbal, sebagian besar dari responden mengatakan tidak merasakan pengaruh signifikan terhadap praktek shalat mereka. Sedikit memilukan memang, mengingat Para Pencari Tuban adalah sinetron yang sebagian besar adegan-adegannya banyak beraktivitas di musholla. Terutama pemeran penting seperti bang Jack yang berperan sebagai marbot mushola.

\section{Aspek Kepedulian Sesama Manusia}

Secara struktual, SMAN 1 Sekampung Udik memiliki pandangan yang pro prilaku peduli sesama manusia, ini tertuang dalam misinya yang berbunyi, 'menciptakan lingkungan yang sehat dan bersahabat bagi kelangsungan kegiatan pembelajaran'. Kata kuncinya adalah 'menciptkan lingkungan yang sehat dan bersahabat, ini mengartikan bahwasanya sekolah ini berharap, warganya lebih mengutamakan kebutuhan dan perasaan orang lain daripada kepentingannya yang bersiat pribadi. Menurut Holder sikap seperti itu disebut dengan sikap orang yang peduli.38 Kepedulian adalah menjadikan diri kita terkait dengan orang lain dengan apapun yang terjadi terhadap orang tersebut. Orang yang peduli tidak akan menyakiti perasaan orang lain. Mereka selalu berusaha untuk menghargai, berbuat baik, dan membuat orang lain senang.

Dalam komunikasi, peduli ini erat kaitannya dengan etika komunikasi. Maksudnya adalah mencoba untuk mengelaborasi standar etis yang digunakan oleh komunikator dan komunikan. Secara situasional, etika komunikasi dilihat dari relevansi bagi setiap penilaian moral.Ini berarti bahwa etika memerhatikan peran dan fungsi komunikator, standar khalayak, derajat kesadaran, tingkat urgensi pelaksanaan, tujuan dan nilai khalayak. Secara religius, kitab suci diapaki sebagai standar mengevaluasi etika

${ }^{38}$ Mark D. Holder and others, "Spirituality, Religiousness, and happiness in Children Aged 8-12 Years," Journal of Happiness Studies, Vol. 9, 13 Nov (2008), 12-4. 
komunikasi. Pendekatan ini membantu manusia untuk menemukan pedoman yang kurang lebih pasti dalam setiap tindakan manusia. Perilaku komunikasi yang legal sangat disesuaikan dengan peraturan yang berlaku dan dianggap sebagai perilaku yang peduli. ${ }^{39}$

Dari sinilah starting point lingkungan yang sehat dan bersahabat akan tercipta. Kepedulian ini bisa diekspresikan dengan berbagai macam seperti berbuat kebaikan, saling sapa, menghormati guru, dermawan, perhatian, dan rasa kasihan.

Lingkungan yang diisi oleh warga yang saling peduli satu sama lain memiliki motivasi seragam yang kemudian menjadi kontrol sosial yang efektif dalam memberikan wawasan religiusitas tinggi, sehingga potensi-potensi yang dapat menimbulkan prilaku menyimpang dapat dihindarkan, harapan terbentuknya lingkungan yang sehat dan bersahabat dapat terwujud dengan baik. Orientasi lingkungan yang sehat dan bersahabat ini sejalan dengan pandangan Viggiani yang menyatakan bawa pendidikan dapat menjadi pengubung antara aspek upaya perbaikan individu dan perbaikan sosial, sehingga masing-masing aspek tersebut dapat saling bersinergi secara harmonis. ${ }^{40}$

Menarik ketika pandangan para tokoh di atas jika dikaitkan dengan kondisi kepedulian responden dalam penelitian ini.

Lingkungan sekolah dalam senyum, sapa dan salam dapat memupuk rasa solidaritas dan kekeluargaan. Karena tiga hal ini dalam pandangan budaya menunjukkan bahwa warga sekolah mempunyai kerukunan, kedamaian, kesantunan, toleransi tinggi dan rasa saling menghormati. Kebiasaan tersebut adalah ciri khas Indonesia, sehingga bangsa Indonesia dikenal oleh bangsa lain sebagai bangsa yang santun dan bersahaja. Konsep peduli ini perlu ditanamkan sejak dini kepada semua lapisan masyarakat. Mengingat dalam konteks Indonesia saat ini, masyarakatnya kehilangan akhlak. Quraish Shihab dalam bukunya teranyanbejudul "Yang Hilang Dari Kita: Akhlak" menekankan bahwa ada yang sedang (terancam) hilang dari masyarakat Indonesia, yakni akhlak. ${ }^{41}$

Apalagi dalam lautan dunia maya yang sesak, semakin hari rasanya akhlak semakin memudar. Contohnya saja yang terjadi baru-baru ini pada KH Mustofa Bisri, cuitannya terkait shalat Jum'at yang dilaksanakan peserta aksi damai 212 di lapangan direspon dengan cuitan tak berakhlak oleh sejumlah netizen.

Nampaknya akhlak kini masih ada pada diri responden. Perubahan prilaku responden yang menonton Para Pencari Tuhan dapat dilihat dari tumbuhnya sikap untuk mengargai diri sendiri dan memiliki toleransi dengan orang lain. Sikap lebih mengargai diri sendiri dan orang lain yang dimiliki responden ini merupakan perubahan yang menjadikan dirinya tidak lagi berkeinginan untuk melakukan perbuatan buruk, yang justru akan merusak dirinya dan sebaliknya. Sehingga, Para Pencari Tuhan berkontribusi positif dalam meningkatkan kepedulian responden. Ini dibuktikan dari pengakuan responden saat wawancara setelah menonton ppt, juga berdasarakn pengamatan tahap

\footnotetext{
${ }^{39}$ Muhamad Mufid, Etika dan Filsafata Komunikasi (Jakarta: Kencana, 2009), 185-186.

${ }^{40}$ Nickde Viggiani "Creating a Healthy Prison: Developing a System Wide Aprroach to Public Helath Within an English Prison,” Prison Service Journal, No. 202, (2012: 13-19.

${ }^{41}$ M. Quraish Shihab, Yang Hilang dari Kita: Akblak (Jakarta: Lentera Hati, 2016), 2-4.
} 
II. Meskipun kita sadari bahwa lingkungan sekolah juga turut berkontribusi dalam menjaga konsistensi kepedulian warga sekolah, namun seluruh responden dalam wawancara tahap dua mengatakan bahwa sinterotn $p p t$ membuat mereka lebih peka dan peduli terhadap lingkungan, ditambah hasil pengamatan yang terlihat respondensemakin memiliki semangat untukpeduli terhadap sesama.Kepedulian responden terhadap sesama prosesnya meningkat. Dari sebagian menjadi keseluruhan respoden. Ini adalah suatu prestasi tersendiri bagi film yang sudah tayang selama sepuluh tahun ini.Patut diapresiasi bersama.

\section{Aspek Membaca Buku Agama}

Membaca adalah suatu proses yang dilakukan oleh seseorang untuk memahami pesan yang hendak disampaikan oleh penulis melalui kata-kata. ${ }^{42}$ Dalam kegiatan membaca ini, terjadi proses pengolahan informasi yang terdiri atas informasi visual dan informasi nonvisual. Informasi visual, merupakan informasi yang diperoleh melalui indera penglihatan, sedangkan informasi non-visual merupakan informasi yang sudah ada dalam benak pembaca. Karena setiap pembaca memiliki pengalaman yang berbedabeda, yang kemudian pengalaman itu digunakan untuk menafsirkan informasi visual dalam bacaan, maka isi bacaan itu akan berubah-ubah sesuai dengan pengalaman pembacanya. ${ }^{43}$ Tak heran jika Muhammad al-Bakri menegaskan bahwa untuk mendapatkan ilmu, sudah semestinya membaca adalah langkah awalnya. ${ }^{44}$

Bahkan, wahyu pertama yang diturunkan oleh Allah SWT kepada nabi Muhammad adalah perintah untuk membaca. ${ }^{45}$ Di dalam al-Qur'an kata qara'a (قرأ) dalam berbagai bentuknya, terulang sebanyak 87 kali dan tersebar ke dalam 41 surah alQur'an. ${ }^{46}$ Sehingga demikian, membaca adalah aktivitas penting. Dengan membaca

42 Henry Guntur Tarigan, Membaca: Sebagai suatu Keterampilan Berbahasa (Bandung: Penerbit Angkasa. 2001), 12-14.

${ }^{43}$ S Nuryati, Pembelajaran Membaca Permulaan Melalui Permainan Bahasa Di Kelas Awal Sekolah Dasar, diakses online dari http:// www.ksdupum.web pada 21 Noember 2016.

${ }^{44}$ Zulkifli Muhammad al-Bakri, Kuasa Iqra : Menguasai Dunia Menikmati Akhirat (Kuala Lumpur: PTS Islamika SDN. BHD, 2012), 21.

45 Pada masa kontemplasi nabi Muhammad di Gua Hira malaikat Jibril muncul di hadapan Muhammad pada sekitar tahun 610 dan berkata "bacalah", namun ternyata Muhammad berkata bahwa Ia tidak tahu caranya membaca. Karena itulah Jibril memeluknya erat sebanyak dua kali dan setelahnya, menyuruh Muhammad membaca ayat yang kemudian menjadi wahyu pertama Muhammad. Sebuah potongan dari surah Al-Alaq ayat 1-5 yang memiliki arti seperti berikut ini: 'Bacalab! Dengan nama Tubanmu yang menciptakan. Membuat manusia dari segumpal darah. Bacalab! Dan tubanmu ialah yang paling mulia.Mengajarkan dengan qalam.Hal-bal yang tidak diketabui manusia."

${ }^{46}$ Lihat Muhammad Fu'a>d 'Abd al-Ba>qi>, al-Mu'jam al-Mufahras li Alfa $>z$ \}alQur'a $>$ n al-Kari $>$ m (Da $>$ ral-Kutub al-Mis\}riyyah, 1364), 539-540. Sedangkan kata qara'a (membaca) yang tersebar dalam 41 surah al-Qur'an adalah al-Qur'an surah an-Nah\}l ayat 98, alIsra >' ayat 14, 45, 71, 93, 106, 9, 41, 45 (kata al-Qur'an), 47, 60, 78, 82, 88, 89, al-Qiya $>$ mah ayat 18,17, al-Syu'ara>'ayat 199, Yu>nus ayat 94, 15, 37, 61, al-'Alaq ayat 1, 3, al-Ha>qqah ayat 19 , al-Muzammil ayat 4, 20, al-A'ra $>$ f ayat 204, al Insyiqa $>$ q ayat 21 , al-A'la $>$ ayat 6 , al-Baqarah ayat 185,228 , an-Nisa >' ayat 82 , al-Ma $>$ 'idah ayat 101 , al-An'>m ayat 19 , at-Taubah ayat111, 
manusia menjadi manusia sesungguhnya dan seutuhnya. Dengan membaca wawasan menjadi terbuka. Karena aktivitas membaca sarat akan manfaat dan mempunyai urgensi yang penting dalam kehidupan. Banyak orang sukses dan cerdas disebabkan membaca buku adalah hobby mereka. Dengan membaca otak akan mendapatkan konsumsi yang tepat. Otak ibaratkan sebuah pedang, semakin diasah akan semakin tajam. Kebalikannya jika tidak diasah, juga akan tumpul. Upaya mengasah otak ini salah satunya dengan membaca.

Sayangnya, urgensi membaca ini nampaknya belum menjadi prioritas 21 responden. Beberapa diantara mereka bahkan mengaku tidak pernah membaca buku, tapi selalu rajin membaca status-status orang di media sosial setiap menit. Gemar membaca, namun bukan membaca buku-buku berkualitas, melainkan membaca komikkomik anime offline maupun lewat online. Perpustakaan sekolah pun jarang mereka kunjungi. Untuk mengetahui lebih jauh mengenai kondisi membaca responden

Frekuensi dan intensitas menonton tiap-tiap remaja berbeda antara satu dengan yang lain, ada yang tinggi dan rendah, bervariatif, namun data mengungkap bahwa minimal para remaja ini menonton $p p t \times 3$ kali seminggu dengan waktu lebih dari 20 menit. Kemudian bagaimana bila frekuensi dan intensitas menonton $p p t \mathrm{x}$ ini dianalisa pengaruhnya dalam pembentukan religiusitas responden? Apakah terdapat hubungan yang signifikan? Setelah penulis analisa, data menunjukkan bahwa menonton $p p t$ jilid $\mathrm{x}$ hanya berpengaruh pada poin peningkatan peduli terhadap sesama, namun tidak mempunyai pengaruh signifikan terhadap praktek shalat dan meyadarkan seseorang dalam meningkatkan pengetahuan keagamaannya melalui membaca buku-buku agama.

Aspek-aspek keterpengaruhan sinetron Para Pencari Tuban ini terlihat wajar. Karena adegan-adegan peduli terhadap sesama selalu menjadi headline dalan sinetron tersebut. Film ini juga merepresentasikan kejadian sehari-hari yang dekat dengan keseharian responden. Meminjam pandangan Bandura, ${ }^{47}$ ada tiga proses responden ini belajar sosial dan terpengaruh dari dari media massa, dalam konteks ini adalah Para Pencari Tuhan. Tiga hal tersebut yaitu proses perhatian, proses pengingatan, dan proses produksi motoris. Proses perhatian terjadi saat seseorang mengamati secara langsung maupun tidak langsung peristiwa. Peristiwa ini dapat berupa gambaran tindakan pada media massa. Misalnya adegan shalat yang dilanjutkan dengan berdizikir. Dari sini kita sudah mulai pada tahap pertama belajar dari media massa. Kita akan mempelajari sesuatu bila kita memperhatkannya. Setiap saat kita menyaksikan banyak perisitiwa, akan sedikit saja yang kita perhatikan. Hal ini mengingatkan peneliti pepatah bijak yang dikatakan oleh Ray Leblond bahwa "You learn something if you pay attention."

$\mathrm{Yu}>$ suf ayat 3 , al-H $\{$ ijr ayat $1,87,91, \mathrm{~T}\{\mathrm{a}>\mathrm{ha}>$ ayat 2,114 , al-Furqa $>\mathrm{n}$ ayat, 30, 32, an-Namal ayat $1,6,72,92$, al-Qas $\}$ as $\}$ ayat 85, ar- $\mathrm{Ru}>\mathrm{m}$ ayat $58, \mathrm{Saba}>$ ' ayat $31, \mathrm{Ya}>\mathrm{si}>\mathrm{n}$ ayat 2,69 , $\mathrm{S}\{\mathrm{a}>\mathrm{d}$ ayat 1 , az-Zumar ayat 27,28 , Fusilat ayat $3,26,44$, az-Zukhruf ayat 3,31 , al-Ah $\} \mathrm{qa}>\mathrm{f}$ ayat 29, Muh $\}$ ammad ayat 24, Qa $>$ f ayat 1, 45, al-Qamar ayat 17, 22, 32, 40, ar-Rahma $>\mathrm{n}$ ayat 2, al$\mathrm{H}$ \{asyar ayat 21 , al-Wa $>$ qi'ah ayat 77 , al-Insa $>\mathrm{n}$ ayat 23 , al-Buru $>$ j ayat 21 , ar-Ra'd ayat 31 , asySyu $>$ ra $>$ ayat 7 dan al-Jinn ayat 1

${ }^{47}$ Albert Bandura, Social Learning Theory (Englewood Cliffs: Prentice Hall, 1977), 24-29. 
Proses kedua adalah proses pengingatan. Peristiwa yang menarik perhatian adalah persitiwa yang menonjol tapi sederhana, terjadi berulang-ulang dan menimbulkan perasaan positif penontonnya. Adegan shalat dalam film $p p t$ yang disiarkan berulangulang, dipraktekan oleh pemeran kawakan akan mendapatkan perhatian dan pengingatan yang besar. Sementara adegan yang diungkapkan secara implisit dan tidak begitu ditonjolkan akan sulit diperhatikan penonton. Hal ini tidak dapat dilakukan penonton jika belum bisa menyimpan adegan tersebut dalam benaknya dan memanggilnya kembali tatkala mereka akan bertindak sesuai contoh yang diberikan. Menurut Bandura, untuk mengingat, peristiwa yang diamati harus direkam dalam bentuk imaginal dan verbal kemudian menunjukkan representasi peristiwa dalam bentuk bahasa. Belum cukup sampai situ, agar peristiwa dapat diteladani, kita bukan saja harus merekamnya dalam memory, tetapi juga harus mempu membayangkan secara mental bagaimana dapat menjalankan tindakan yang diteladani. ${ }^{48}$

Proses ketiga adalah reproduksi motorik, artinya menghasilkan kembali tindakan yang diamati.Dorongan ini muncul saat melihat orang lain yang berbuat tindakan sama yang mendapatkan ganjaran baik akibat perbuatannya. Dalam adegan-adegan Para Pencari Tuhan $\mathrm{x}$ aktor yang berbuat baik terhadap tetangga, membantu sesama saat kesusahan mendapatkan ganjaran yang baik pula kepada sesama. Akhirnya, tindakan teladan itu akan dilakkan bila diri sendiri mendorong tindakan itu. Dorongan diri sendiri itu mungkin muncul dari perasaan puas, gembira, keren dan asyik.

Dengan demikian, ditemukan bahwa yang secara keseluruhan memiliki hubungan terhadap religiusitas remaja adalah seberapa tinggi nilai-nilai religius yang ditonjolakan dalam sinetron Para Pencari Tuhan, juga seberapa sering responden menonton acara tersebut. Sehingga, nilai-nilai yang sering ditonjolkan itu akan difilter oleh penonton yang kemudian memengaruhi sikap mereka. Meskipun begitu, sekalipun nilai-nilai dan frekuensi itu tinggi, gaya hidup, peran keluarga, sekolah dan rekan sebaya juga turut berperan terhadap semakin tinggi hubungannya dengan religiusitas remaja tersebut. Begitu pun sebaliknya.

Setelah dianalisis, pada hakekatnya, kekuatan konstruksi Para Pencari Tuban jilid x terletak pada tiga aspek.

Pertama, kekuataannya dalam menyuntik doktrin dan memilih diksi dontrindoktrin tersebut ke dalam pemikiran responden sebagai penonton. Pembenaran doktrin ini dilakukan secara tegas melalui proses audio-virtual televisi, yang menggambarkan kehidupan sehari-hari.

Kedua, pengulangan terus-menerus merupakan metode televisi yang tepat sasaran untuk mengontruksi sesuai apa yang diagendakan acara tersebut. Para Pencari Tuban secara konsisten terus mengulang-ngulang adegan-adengan kepedulian sesama, sosialisasi kehidupan, problematika hidup dalamadegan-adegannya. Pengulangan ini memberikan makna pada penontonnya, hingga berdampak bagi relegiusitas mereka.

48 Albert Bandura, Social Learning Theory (Englewood Cliffs: Prentice Hall, 1977), 24-29. 
Ketiga, responden remaja yang belum cukup mampu mengkritisi secara dalam konten yang ada dalam Para Pencari Tuhan. Hal ini menjadikan apa yang mereka tonton, itulah yang mereka cerna. Baik maupun buruk, di mata remaja sama saja.

Keempat, mitos media sebagai ikon publik merefleksikan berita positif semakin positif. Dalam sinetron ini, hingga dapat menyulap seseorang biasa menjadi publik figur dalam sekejap mata. Menyulap respon terhadap suatu permasalahan yang disajikan ppt jilid x, menjadi alternatif solusi di kehidupan nyata.

Pada perkembagannya, manusia telah napak tilas dalam empat era, mulai dari era berburu, bertani, industri dan hari ini era informasi. ${ }^{49}$ Menimbang hal itu, maka era informasi hari ini menjadikan peran media telvisi penting. Karena media ini dapat menyampaikan pesan-pesan secara serentak kepada khalayak ramai. Keseluruh pelosok dunia hanya melalui sebongkah kotak ajaib murah. Masalahnya kemudian adalah, apa yang disampaikan media ini tidak semua nya positif. Bahkan informasi positifpun dapat diracik menjadi negatif. Ditambah informasi positif juga belum tentu mempunyai dampak positif. Juga masyarakat yang masih berpola fikir era pertanian dianggap belum bisa relevan dengan konten-konten televisi yang cenderung kotennya membidik sasaran masyarakat berpola fikri era informasi.

Contoh nya saja sinetron-sinetron bernuansa percintaan dan perkelahian yang disisipi sedikit nilai moral. Seharusnya acara seperti ini dapat ditangkap secara positif oleh penonton, namun kenyataan mengatakan sebaliknya. Acara-acara tersebut digemari bukan karena nilainya, melainkan karena wanita-wanita seksinya, pria bermotor ugalugalan yang dianggap keren oleh remaja, juga kostum pemerannya yang 'aduhai'. Memang selain faktor individu, maraknya minat penonton ini disebabkan oleh kemudahan penonton untuk menonton acara ini dari kotak ajaib.

Bila film seperti itu dapat disaksikan dengan mudah, kemudahan itu juga dirasakan film-film yang bernuansa religius. Penelitian ini membuktikan bahwa film-film religius memiliki pengaruh, meskipun berbeda-beda namun sangat berarti bagi religiusitas remaja. Dari gambaran ini, dapat dibayangkan bahwa betapa acara-acara televisi telah merenggut perhatian remaja. Bahkan telah menjadi daily activities, new friend, and loyal friend bagi remaja. Terbukti dengan data yang didapat penulis, meskipun di bulan suci Ramadhan, frekuesni menonton remaja masih tinggi, bahkan boleh dikatakan mereka hafal betul acara apa, sedang tayang jam berapa, dan di satsiun tv apa.

Dari analisis tersebut beberapa hal yang bisa dipahami. Pertama, pengaruh Para Pencari Tuhan terhadap kepedulian remaja lebih kuat jika dibandingkan pengaruh Para Pencari Tuhan dengan aspek shalat dan membaca buku-buku agama. Pengaruh $p p t$ terhadap shalat dan membaca buku agama tergolong lemah, yang kemudian menunjukkan kontribusi yang kecil. Hal ini kemudian menunjukkan bahwa Para Pencari Tuhan lebih banyak memberikan dampak pada aspek religiusitas yang bersifat objektif, seperti baiknya interaksi sosial, realisasi diri dan fungsi psikologis. Hal ini sangat

${ }^{49}$ Ilham Prisgunanto, Komunikasi Pemasaran Era Digital (Jakarta: Prisani Cendikia, 2014), $2-5$. 
mungkin terjadi karena film ini sangat penuh dengan nilai-nilai sosial dan norma-norma, maka sinetron ini menjadikan penontonnya untuk menjadi manusia yang sesuai dengan norma dan nilai tersebut.

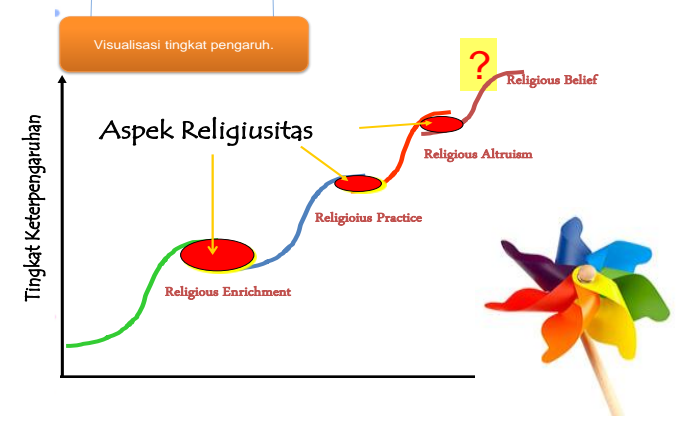

Untuk memudahkan pembaca, visualisasi di atas secara singkat menjelaskan hasil analisis peneliti mengenai tingkat pengeruh ppt jilid x terhadap empat aspek religiusitas remaja. Visualisasi ini disusun sesederhana mungkin, setelah peneliti menganalisa permasalahan ini berdasarkan wawancara, pengamatan dakumentasi sebelum dan sesudah responden menonton ppt jilid x. Nyatanya, yang paling rendah adalah pengaruh terhadap Religious Enrichment, kemudian disusul religious Practice dan terakhir yang paling menonjol adalah aspek Religious Altruism.

\section{Penutup}

\section{A. Kesimpulan}

Penelitian ini mengkaji tentang dampak film Islami terhadap perkembangan religiusitas remaja, dengan menjadikan remaja di SMAN 1 Sekampung Udik dan sinetron Para Pencari Tuban jilid x sebagai objek kajian. Keberadaan penelitian ini merupakan bagian dari komunikasi Islam (Islamic communication). Dalam penelitian ini, hubungan antar responden dan film dikaji dengan teori religiusitas dan teori dampak media. Segala hal yang menyangkut religiusitas responden sebelum dan sesudah menonton Para Pencari Tuhan jilid x diklasifikasikan dan dianalisis dengan teori tersebut. Dengan demikian, penelitian ini memfokuskan kajian pada tiga aspek utama, yaitu: pengaruh Para Pencari Tuban terhadap praktek shalat responden, pengaruh Para Pencari Tuban terhadap kepedulian responden, dan pengaruh Para Pencari Tuban terhadap kesadaran responden dalam meningkat ilmu agama melalui membaca buku. Dari paparan dalam pembahasan di atas, dapat disimpulkan bahwa:

1. Sinetron Para Pencari Tuhan cenderung tidak memberikan andil pada kerajinan praktek shalat responden pada level behaviorisme. Film ini hanya berpengaruh sebatas level kognitif dan afektif saja, tanpa sama sekali menyentuh level 
behaviorisme. Sedikit memilukan memang, mengingat Para Pencari Tuban yang sudah tayang selama sepuluh tahun ini adalah sinetron yang sebagian besar adeganadegannya banyak beraktivitas di musholla. Terutama pemeran penting seperti bang Jack yang berperan sebagai marbot mushola.

2. Perubahan prilaku responden yang menonton Para Pencari Tuban dapat dilihat dari tumbuhnya sikap untuk menghargai diri sendiri dan memiliki toleransi dengan orang lain. Sikap lebih menghargai diri sendiri dan orang lain yang dimiliki responden ini merupakan perubahan yang menjadikan dirinya tidak lagi berkeinginan untuk melakukan perbuatan buruk, yang justru akan merusak dirinya dan sebaliknya. Dengan demikian, Para Pencari Tuhan berkontribusi positif dalam meningkatkan kepedulian responden. Meskipun kita sadari bahwa lingkungan sekolah, orang tua, dan rekan sebaya juga turut berkontribusi dalam menjaga konsistensi kepedulian responden, namun seluruh responden dalam wawancara tahap dua mengatakan bahwa sinterotn ppt membuat mereka lebih peka terhadap lingkungan, diperkuat dengan hasil pengamatan yang terlihat responden semakin peduli terhadap sesama.

3. Dari hasil analisis dari aspek ini, maka jalan terbaik kiranya yang bisa ditempuh crew Para Pencari Tuban adalah meramu ulang, dan mengevaluasi scene-scene-nya jika ingin berdampak pada kesadaran menigkatkan pengetahuan agama melalui membaca buku-buku pada remaja. Pasalnya, film yang sudah tayang selama sepuluh tahun itu ternyata tidak berkontribusi dalam meningkatkan kesadaran responden dalam aspek membaca buku-buku agama.

4. Namun terlepas dari semua itu, tetap ada kontribusi ppt jilid x terhadap religiusitas remaja, yaitu pada aspek kepedulian. Karena di dunia persinetronan, menjadi acara yang mempunyai rating dan share penonton yang tinggi mengartikan pihak penyelenggara mempunyai program yang sukses. Karena itu, pada dasarnya, penyebutan banyak dampak negatif sinetron-sinetron yang berkeliaran di televisi ini bisa saja didukung oleh kelompok yang pro, dan ditolak oleh kelompok yang kontra. Dan Para Pencari Tuhan adalah salah satu film yang hadir sebagai antitesa film-film negatif tersebut. Oleh karena itu film ini patut untuk diapresiasi setinggi-tingginya. Meskipun ada beberapa catatan evaluasi yang menjadi pekerjaan rumah bsgi seluruh crew film.

\section{B. Saran}

Berdasarkan hasil kajian ini, maka ada lima saran yang penulis ajukan kepada sinetron Para Pencari Tuhandan SMAN 1 Sekampung Udik:

1. Pertama, perlu adanya pengawasan terus-menerus dan berkesinambungan serta keteladanan dari seluruh guru SMAN 1 Sekampung Udik dalam setiap rangkaian pelaksanaan program-programnya, baik keagamaan mapun non-keagamaan.

2. Kedua, perlu adanya jalinan kerjasama yang lebih luas dan lebih erat antara pihak SMAN 1 Sekampung Udik dengan pihak keluarga siswa dan masyarakat setempat. Hal ini dalam rangka memantau perkembangan religiusitas siswa, sehingga prilaku siswa di dalam maupun di luar sekolah dapat terkontrol teratur. Perilaku menyimpang dapat diminimalisir. 
3. Jika film Para Pencari Tuhan hendak tayang tahun depan, dan ingin berkontribusi terhadap religiusitas audiens remajanya, sebagai saran, penulis telah membuat kriteria-kriteria masukan untuk ditinjau ulang dari berbagai sisi, yaitu 1) perumusan konten cerita, 2) peracikan humor dan percintaan, 3) segi penyajian cerita, 4) profesionalitas skenario, 5) pemilihan pemeran dan 6) dari segi kekuatan dialog

4. Selanjutnya, film ini bisa diarahkan untuk lebih merespons isu-isu lokal dalam upaya penguatan Islam dan keindonesiaan. Apalagi film ini telah tayang satu dekade, tentu kepentingan Islam, publik dan negara harus dikedepankan dari kepentingan kelompok tertentu.

5. Selain untuk kedua hal tersebut di atas, saran sekaligus rekomendasi juga ditujukan kepada para peneliti berikutnya. Penelitian ini bukanlah penelitian yang final dan masih membutuhkan banyak analisis mendalam. Tentunya dengan data-data lain yang mendukung. Mungkin penelitian berikutnya akan menemukan fakta lain tentang dampak film religius. Sebab perkembangan film religius ini sangat dinamis.. Banyak perubahan yang akan terjadi di dunia perfilman. Ini patut diperhatikan untuk menjadi ruang analisis peneliti berikutnya.

\section{Daftar Pustaka}

" "Darut Tawhid: New Approach to Dakwah for Peace in Indonesia." Jurnal Kajian Dakwah dan Komunikasi.Volume VIII, Nomor 01 (Juni 2006), 15.

Aziz, Moh Ali. Ilmu Dakwah. Jakarta: Kencana, 2009.

Bakti, Andi Faisal. Applied Communication to Dakwah for Peace, makalah dipresentasikan pada kuliah umum di Pascasarjana UIN Aluiddin Makassar ,1 September 2009.

D'haeyere, Hilde. "Slapstick On Slapstick: Mack Sennett's Metamovies Revisit the Keystone Film Company.’'Journal Film HistoryVol. 26, No. 2, (2014).

Holder, Mark D. and others. "Spirituality, Religiousness, and happiness in Children Aged 8-12 Years," Journal of Happiness Studies, Vol. 9, 13 Nov (2008).

Hovland, C.I., A.A Lumsdaine, and F.D. Sheffield.Experiments on MassCommunications. Newyork: Wiley. 1949.

Ishaq, Ropingi. "Dakwah di Tengah Industrialisasi Media."Jurnal Komunikasi Islam.Volume 03, Nomor 01, (2013).

Kumar, Arvind. Encyclopedi of Mass Media and Communication. New Delhi: Anmol Pulication PVT. LTD, 1998.

Lyden, John C. Film as Religion; Myth, Moral and Ritual.USA: Network University Press, 2003.

Manier, David. "What is Left Creation." Journal Psycritiques American Psychological Association, Vol. 59, No. 43, Article 8 (2014). 
24 |Jurnal Dakwah dan Komunikasi, Vol. 3, No. 1, 2018

Mccombs, Maxwell dan Amy Reynolds.News Influence on Our Pictures of the World. London: Mahwah, 2002.

McQuail, Denis dan Seven Windahl.Communication Models for Study of Mass Communications. New York: Longman, 1993.

Moleong, Lexy J. Metodelogi Penelitian Kualitatif. Bandung: Remaja Rosdakarya, 2006.

Mufid, Muhamad. Etika dan Filsafata Komunikasi. Jakarta: Kencana, 2009.

Munadi, Yudhi. Media Pembelajaran Referensi. Jakarta: GP Press Groupmaret, 2013.

Peraturan Pemerintah Republik Indonesia Nomor 18 Tahun 2014 tentang Lembaga Sensor Film, 1-36.

Tiliouine, Habib dan Abbes Belgoumidi. "An Exploratory Study of Religiousity, Meaning in Life and Subjective Wekkbeing in Muslim Students From Algeria," The Internasional Society for Quality of Life Studies (SQOLS) 4 Springer (2009).

Tuner, Bryan S. New Spiritualities, The Media and Global Religion, dalam Pattaa kittiarsa, Religion Commodification in Asia dalam. London and New york: Routledge Taylor and Fanncis Group, 2008.

Undang Undang Dasar (UUD) Nomor 33 Tahun 2009 tentang Perfilman.

Viggiani, Nickde. "Creating a Healthy Prison: Developing a System Wide Aprroach to Public Helath Within an English Prison,” Prison Service Journal, No. 202, (2012).

Wolfram, Paul. "Career View, What is film?" Career Development and Employment, University Of wellington, Issue No 59. (2011). 